\title{
Client's Satisfaction toward Communication Skills among Doctors in Primary Health Care Centers in Erbil City
}

\section{Zhian Mueen Shekho}

Department of Community, College of Nursing, Hawler Medical University, Erbil, Kurdistan Region, Iraq.

\section{E-mail: zhyan.moen@gmail.com}

\section{Kareem Aziz Fatah}

Department of Community, College of Nursing, Hawler Medical University, Erbil, Kurdistan Region, Iraq.

\section{E-mail: drkareem2009@yahoo.com}

\section{ABSTRUCT:}

Back ground and Objectives: Effective communication is important at all steps of human life, most especially in healthcare organizations because it enables good relationships between doctors and clients and helps them in challenging healthcare choices. This study aimed to identify level of satisfaction of clients with communication of doctors in primary health care centers and to find out the association between client's satisfaction and their socio-demographics.

Methods: Quantitative design, cross-sectional descriptive study was conducted to determine the level of client's satisfaction toward communication skills of doctors in four primary health care centers. The data were collected at the period of $15^{\text {th }}$ of April, 2019 to $1^{\text {st }}$ of July, 2019. So, 300 clients were chosen randomly.

Result: The mean age \pm SD was $35.0 \pm 10.8$ years, ranging from 19 to 70 years. The median was 33 years. The majority (71\%) of the clients aged less than 40 years. Around two thirds (64.3\%) of the clients were females, and $80.3 \%$ of the clients were Muslims. Around one third (34.3\%) of the clients attended the PHC centers for immunization, 32\% for checkup, and $23 \%$ for medical treatment. $34.4 \%$ of the clients visit the PHC center more than four times per year, $26 \%$ visit the center four times per year, and $25 \%$ of the clients visit the center three times per year. There was no significant association between the communication skills of doctors with the following variables: age of the client $(p=0.096)$, gender $(p=0.315)$, religion $(p=0.653)$, educational level $(p=0.615)$, type of health care services $(p=0.469)$, and number of visits per year $(\mathrm{p}=0.089)$. 
Conclusion: study revealed that $26 \%$ of clients who were very satisfied with physician's communication skills, and $36.3 \%$ were satisfied, and $6.7 \%$ dissatisfied. There were no significant association between the client satisfactions of doctors with their socio-demographical characteristics.

Key words: communication skill, client satisfaction, doctors.

\section{INTRODUCTION:}

Communication skills between doctors and clients are one of the most important issues for improving clients' satisfaction. In the health setting, communication not only concentrates on sharing information regarding problems, causes, and possible treatments but also acknowledges the clients' emotional needs. (1)

Studies surrounding the effectiveness of client-centered care have emerged during the last decade. However, it does not appear that the idea that a doctor's purpose is to relay information and heal clients as best he/she can with as little interaction as possible has gone by the wayside. (2)

Good communication skills are essential to therapeutic and other healthcare practice. Communication is important not only to client interaction but also within the healthcare team. The benefits of communication include good functioning relationships and increased client satisfaction. Active communication may increase client understanding of treatment, improve compliance and lead to improved health outcomes.(3)

However, a recent study indicates that health maintenance organizations, doctors, and insurance companies have begun to take an interest in this field of communication because effectively communicating with one's clients may be the difference between getting sued and not getting sued.(4)

Therefore, client satisfaction and the mutual benefits to clients and healthcare systems particularly to physicians have been widely researched and emphasized recently. (5)

Client satisfaction is influenced by several factors that include different aspects of healthcare services such as increased primary health care centers facilities, increased number of personnel, and accessibility to primary healthcare services and reduced wait time for receiving healthcare services.(6)

However, effective communication skills are one of the important tools providing doctor's ways to treat clients, determine their problems, care for and help them. Effective communication is a vital characteristic of high-quality client care. Through effective communication, doctors are able to meet client needs and improve their well-being. (7)

To succeed in this work, the professionals need to practice good communication skills. provision of basic healthcare as well as emotional and psychological support is enhanced through effective communication during health care.(8) The purpose of this study was to determine the level of satisfaction of clients with communication of doctors in primary health care centers and find out the association between client's satisfaction and their socio-demographic 


\section{METHOD:}

The study is descriptive study/cross sectional design was conducted to assess the level of client's satisfaction towards doctor's communication in primary health centers in Erbil city. The data were collected during the period of $15^{\text {th }}$ April, 2019 to $1^{\text {st }}$ July, 2019. the setting of the study was included four primary health care centers (Nazdar Bamarni, Muhammad Bajalan, Tayrawa,and Mala Fandi) in Erbil city according to geographical area a of Erbil city. A nonprobability (purposive) sampling technique was based to determine sample size, which include 300 clients out of 1350 as a total population who attend to primary health care centers during period of data collection, depend on online sample size calculator and para meters of calculation sample size included (confidence level $=95 \%$, Margin of error $=5 \%$.). Inclusion and exclusion criteria: Client who had desire to participate with study and 18 years and older. And exclusion all clients who wasn't desire to participate in the study and those clients who had psychological problem. Data was gathered through interview technique (face to face style) by using the questionnaire format which prepared by investigator. The standard questionnaire was used for data collection. The questionnaire included the following parts: Part one: Socio demographic characteristics, this part is concerned with socio demographical characteristics of clients were included age, gender, religion, level of education, type of health care services and number of visited per year. Part two: client's satisfaction towards communication skills among doctors. Therapeutic communication skills measured using the Communication assessment tool (CAT)(9).CAT measures client perceptions of communication with doctors. The CAT includes 14 items and Assessment of level client satisfaction by using Likert scale. To standardize satisfaction, were adopted the scale developed by Likert (2009) which measured satisfaction 5-point response scale (1= very dissatisfied, $2=$ dissatisfied, $3=$ neutral, $4=$ satisfied, $5=$ very satisfied). It was originally designed to assess a client's communication.

Ethical consideration was a main principle of data collection. Permission was taken from ethical committee in college of nursing/hawler medical university and was approved from general director of health in Erbil.

Data were analyzed by using the Statistical Package for Social Sciences (SPSS, version 22). Numerical variables were summarized as means and standard deviations. Categorical variables were presented as proportions. Chi square test of association was used to compare proportions. Fisher's exact test was used when the expected count of more than $20 \%$ of the cells of the table was less than 5 . A p value of $\leq 0.05$ was considered statistically significant. 


\section{RESULT:}

Three hundred clients participated in the study. Their mean age \pm SD was $35.0 \pm 10.8$ years, ranging from 19 to 70 years. The median was 33 years. The majority $(71 \%)$ of the clients aged less than 40 years as presented in Table 1. Around two thirds $(64.3 \%)$ of the clients were females. The table shows that $80.3 \%$ of the clients were Muslims.

It has evident in Table 1 that around one quarter (24.3\%) were graduates of institutes, $22 \%$ were illiterate, and $20.7 \%$ were college graduates.

Table 1. Socio-demographic characteristics of the samples (frequency and percentage).

\begin{tabular}{lll}
\hline Variable & frequency & $(\%)$ \\
\hline Age (years) & 110 & $(36.7)$ \\
$<\mathbf{3 0}$ & 103 & $(34.3)$ \\
$\mathbf{3 0 - 3 9}$ & 54 & $(18.0)$ \\
$\mathbf{4 0 - 4 9}$ & 33 & $(11.0)$ \\
$\geq \mathbf{5 0}$ & & \\
Gender & 107 & $(35.7)$ \\
Male & 193 & $(64.3)$ \\
Female & & \\
Religion & 241 \\
Muslim & 48 \\
Christian & 11 & $(80.3)$ \\
Others & & $(16.0)$ \\
Educational level & 300 \\
Illiterate & 66 & $(3.7)$ \\
Able to read and write & 19 & $(100.0)$ \\
Primary school graduate & 32 & $(22.0)$ \\
Secondary school graduate & 48 & $(10.7)$ \\
Institute graduate & $73.0)$ \\
University and above & 62 & \\
\hline Total & & \\
\hline & & \\
\hline
\end{tabular}


Around one third (34.3\%) of the clients attended the PHC centers for immunization, 32\% for checkup, and $23 \%$ for medical treatment as presented in Table 2 . The table 2 shows that $34.4 \%$ of the clients visit the primary healthcare center more than four times per year, $26 \%$ visit the center four times per year, and $25 \%$ of the clients visit the center three times per year.

Table 2. type of health care services

\section{Frequency $\quad(\%)$}

\section{Type of health care services}

Medical treatment $\quad 69$

Checkup

96

Immunization program

103

Family planning

31

Others

1

No. of visits per year

Once 5

Twice

39

Three times

75

Four times

78

More than four times

103

\section{Total}

300

(100.0)

*Very dissatisfied score is less than 15; dissatisfied score = 15-28; neutral scores = 29-42; satisfied scores = 43-56; and very satisfied scores $=57-70$.

According to the Likert's scale that have been used in the study, 4 and 5 scores were given to the 'satisfied' and 'very satisfied'. By multiplying 4 by 14 (which is the total number of communication skills items), the result is 56 (out of 70 scores). Accordingly, those who scored 56 and more were considered as 'satisfied' and the rest were less satisfied.Table3 shows that $26 \%$ of patients who were very satisfied with doctor's communication skills $(\mathrm{p}=0.002)$. 
Table 3. level of total satisfaction with doctor's communication skills.

\begin{tabular}{llll}
\hline clients' & Doctors & P value \\
\cline { 2 - 4 } satisfaction* & frequency & $\mathbf{( \% )}$ & \\
\hline Dissatisfied & 20 & $(6.7)$ & \\
Neutral & 93 & $(31.0)$ & \\
Satisfied & 109 & $(36.3)$ & \\
Very satisfied & 78 & $(26.0)$ & 0.002 \\
\hline Total & 300 & $(100.0)$ & \\
\hline
\end{tabular}

Table 4 shows also that there was no significant association between the CS of doctors with the following variables: age of the client $(p=0.096)$, gender $(p=0.315)$, religion $(p=0.653)$, educational level $(p=0.615)$, type of health care services $(p=0.469)$, and number of visits per year $(p=0.089)$.

Table 4. Degree of satisfaction with doctors' communication skills by the studied factors.

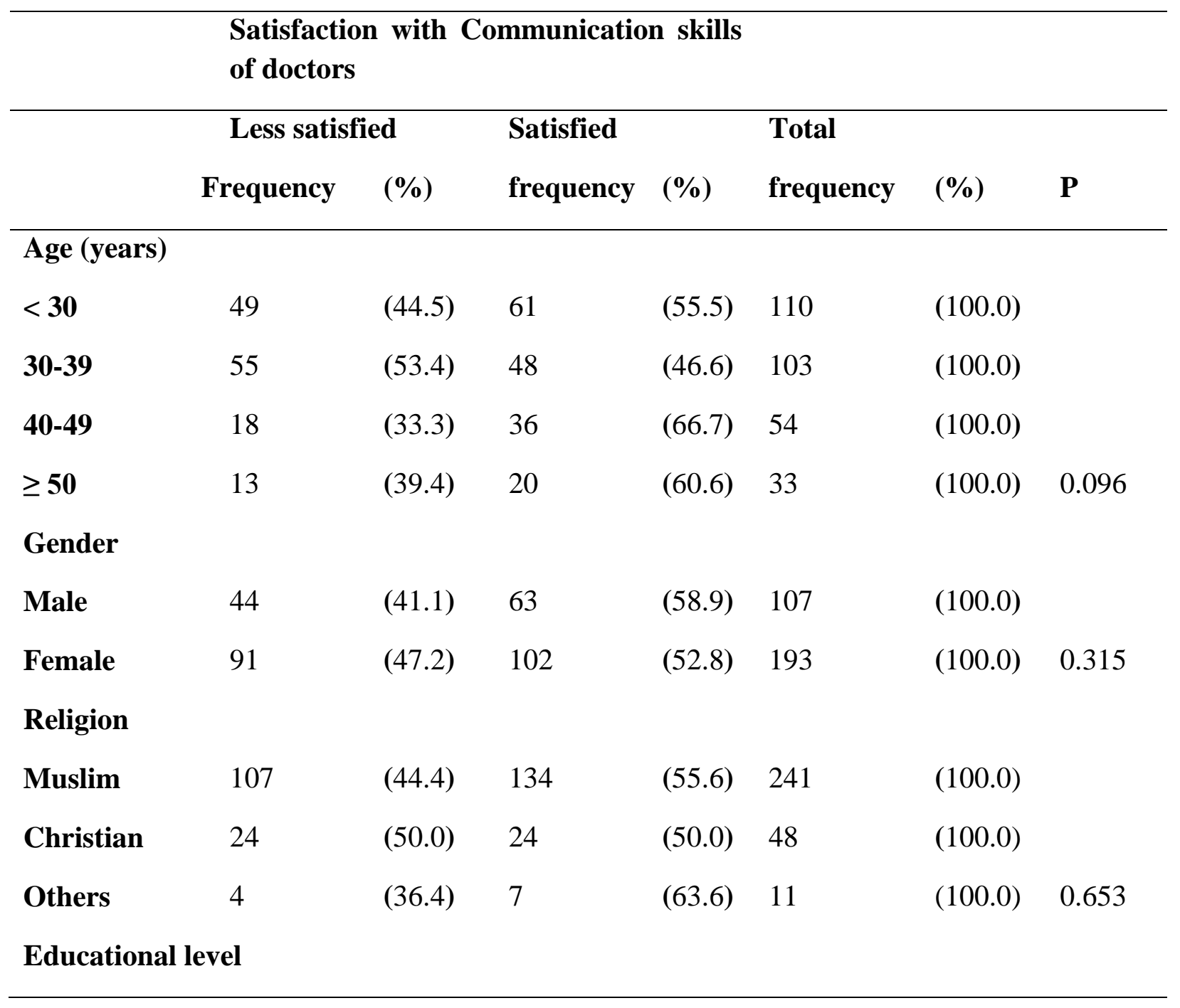


Journal of University of Raparin

\begin{tabular}{|c|c|c|c|c|c|c|c|}
\hline Illiterate & 28 & $(42.4)$ & 38 & $\begin{array}{l}(57.6) \\
\end{array}$ & 66 & $(100.0)$ & \\
\hline $\begin{array}{l}\text { Read and } \\
\text { write }\end{array}$ & 5 & $(26.3)$ & 14 & (73.7) & 19 & $(100.0)$ & \\
\hline Primary & 16 & $(50.0)$ & 16 & $(50.0)$ & 32 & $(100.0)$ & \\
\hline Secondary & 22 & $(45.8)$ & 26 & $(54.2)$ & 48 & $(100.0)$ & \\
\hline Institute & 34 & $(46.6)$ & 39 & $(53.4)$ & 73 & $(100.0)$ & \\
\hline University & 30 & $(48.4)$ & 32 & (51.6) & 62 & $(100.0)$ & 0.615 \\
\hline \multicolumn{8}{|c|}{ Type of health care services } \\
\hline $\begin{array}{l}\text { Medical } \\
\text { treatment }\end{array}$ & 28 & $(40.6)$ & 41 & $(59.4)$ & 69 & $(100.0)$ & \\
\hline Checkup & 45 & (46.9) & 51 & $(53.1)$ & 96 & (100.0) & \\
\hline Immunization & 50 & $(48.5)$ & 53 & $(51.5)$ & 103 & $(100.0)$ & \\
\hline $\begin{array}{l}\text { Family } \\
\text { planning }\end{array}$ & 11 & $(35.5)$ & 20 & $(64.5)$ & 31 & $(100.0)$ & \\
\hline Others & 1 & (100.0) & 0 & $(0.0)$ & 1 & $(100.0)$ & 0.469 \\
\hline \multicolumn{8}{|c|}{ No. of visits per year } \\
\hline One & 2 & $(40.0)$ & 3 & $(60.0)$ & 5 & (100.0) & \\
\hline Two & 12 & $(30.8)$ & 27 & $(69.2)$ & 39 & (100.0) & \\
\hline Three & 28 & $(37.3)$ & 47 & (62.7) & 75 & (100.0) & \\
\hline Four & 41 & $(52.6)$ & 37 & (47.4) & 78 & (100.0) & \\
\hline $\begin{array}{l}\text { More } \\
\text { four }\end{array}$ & 52 & $(50.5)$ & 51 & (49.5) & 103 & (100.0) & 0.089 \\
\hline Total & 135 & $(45.0)$ & 165 & $(55.0)$ & 300 & $(100.0)$ & \\
\hline
\end{tabular}

*By Fisher's exact test. 
Key for Table 5 .

\begin{tabular}{|l|l|}
\hline & Questions and items of communication skills \\
\hline Q1 & Start communication with greets talks with face beaming and smiling. \\
\hline Q2 & Having integrity and privacy in communication. \\
\hline Q3 & Asking you about your health problems properly. \\
\hline Q4 & Attention to physical space conditions (light, sound and ventilation) and comfort. \\
\hline Q5 & Should be concentrated on you during interview. \\
\hline Q6 & At the end of the communication ending a polite manner. \\
\hline Q7 & Not talking tough and dignified. \\
\hline Q8 & Use appropriate words simple and understandable. \\
\hline Q9 & Explain for you about referring you to other hospital on need \\
\hline Q10 & Discussing the goals of consultation and education regarding your health problems. \\
\hline Q11 & Letting you tell your story; listening carefully, not interrupting you while you're talking. \\
\hline Q12 & Maintained appropriate eye contact throughout interview with you \\
\hline Q13 & Summarize the discussion at the end of interview to better understand the problem. \\
\hline Q14 & Give you sufficient time to answer all question. \\
\hline
\end{tabular}

\section{DISCUSSION:}

Successful healing process requires that health care professionals, particularly doctors, feel and practice effective therapeutic relationship with their clients. The communicating effectively with clients is considered the heart of all clients' care parts. This requires that physicians and clients should have an agreement on what and how communication skills can be real. One tactic is through finding clients' satisfaction about physicians' communication skills.

The study was conducted among clients that attended in primary health care centers their mean age \pm SD was $35.0 \pm$ 10.8 ranged from 19 to 70 years old. Result of the study showed that the majority of samples were the median was 33 years. The majority (71\%) of the patients aged less than 40 years, and this result was similar with a study carried by Narinja and Highhat in 2012, which mentioned the range of and the mean (SD) age of patients were 18-80 and $38 \pm 14$ years.(10) 
In current study showed around two thirds $(64.3 \%)$ of the patients were females and (35.7\%).

This finding similar with study that carried by Biglu and Natiq in 2017. (11)

In same study we found that $(80.3 \%)$ of the clients were Muslims, and (16.0\%).

Around one quarter $(24.3 \%)$ were graduates of institutes, $22 \%$ were illiterate, and $20.7 \%$ were college graduates. This study similar with a study that carried by Hamdan-Mansour and Aboshaiqah in 2014.(12).

Around one third $(34.3 \%)$ of the clients attended the PHC centers for immunization, 32\% for checkup, and $23 \%$ for medical treatment. shows that $34.4 \%$ of the clients used to visit the PHC center more than four times per year, $26 \%$ visit the center four times per year, and $25 \%$ of the clients visit the center three times per year. This study discovered that the most of the clients were satisfied about physician's communication skills were represented $26 \%$ of clients who were very satisfied with physician's communication skills and (36.3\%) of clients were satisfied. Therefore (31.0\%) of clients were indicated neutral level, and (6.7\%) dissatisfied about their communication skills. this study was similar with a study carried by Robert and Hellen in 2013, which found that $70 \%$ of the clients were satisfied with the existing communication skills except $30 \%$ who were dissatisfied.(13)

Therefore, there doctors and clients should entirely agree on be satisfied about doctor's communication skills at the same level to avoid confusion and disagreement on other element of care plan. Moreover, the results in this study infer that clients were able to evaluate doctors' communication skills better than doctors do for themselves.

In a current study revealed that $56.3 \%$ of the clients were satisfied with the communication skills of the doctors. This is low compared to other similar studies. A study in Pakistan showed 79\% clients' satisfied with communication done Ashref,in 2012.(14) This discrepancy might be due to the difference of subjective natures of respondents, availability of safe working environments and sample size. But this finding is higher as compared to the study conducted in Ghana (35\%) don by Hildingsson in 2005. (15)

This result agrees with the study that carried by Kei in 2013 that found that $70 \%$ of the clients were satisfied with the existing communication skills except a significant number (30\%) who were dissatisfied. Quality face to face communication between health providers and clients lead to information transfer that affects compliance, adherence, clinical outcomes and satisfaction Halls in 2003. Supports the findings by observing that addressing issues of satisfaction may influence the client's willingness to reduce high risk behavior during pregnancy which ultimately impact on the health of the mother and the newborn. Also, parizadehin 2004, argues that effective human communication process is the main ingredient in the doctors-client relationship. (16) This phenomenon was found to be true in this study in that the satisfaction levels for (doctors) were nearly equal. We agreed that this could have been because the doctors showed more empathic responses and more concern as perceived by clients, which had an impact on clients' understanding of their illnesses and health outcomes. Concerned providers are more likely to tell their clients the names and causes of their illnesses to increase their understanding, thus helping them to manage their illnesses, leading to increased satisfaction levels. 


\section{CONCLUSION :}

Current studies evaluating the helpfulness of initiatives to improve the communication between doctors and clients in primary healthcare centers suggest a positive effect on client satisfaction.

Clients should be educated in asking information and expressing their preferences, and doctors must recognize the need to attain suitable communication skills to better understand clients' overall needs, teach information in a sensitive manner, and respond to more assertive clients.

This study found that patients had high level of satisfaction about their doctors' communication skills. Consequently, there is a possibility that doctors might be unable to adequately meet clients' needs and improve their clients' wellbeing and provide a quality of health care. Doctors need to improve their communication skills and have to use their clients' feedback and evaluation as indicators for their performance. Communication is the mean in which doctors know the outcome of their care, thus; doctors need to appropriately consider seriously their effective practice of communication skills with their clients.

\section{CONFLECT OF INTREST}

The authors have no any conflict of interest. 


\section{رضى المواطنين حول مهارات التواصل بينهم و بين الاطبا في المراكزالرعاية الصحية الأولية في مل ينة اربيل}

قسم المجتمع، كلية التمريض، جامعة أربيل الطبية، أربيل، إقليم كردستان، العراق. zhyan.moen@gmail.com

قسم المجتمع، كلية التمريض، جامعة أربيل الطبية، أربيل، إقليم كردستان، العراق. drkareem2009@yahoo.com
ريَان معين شِيَخْو

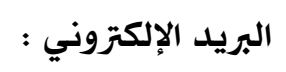

كريم فتاح عزيز البرزنجى

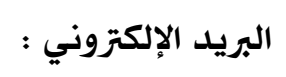

الخلفية والأهداف: التواصل الفعال مهم في جميع مراحل حياة الإنسان ، وخاصة في مؤسسات الرعاية الصحية لأنه يتيح علاقات جيدة بين الأطباء و المواطنين ويساعدهم في تحدي خيارات الرعاية الصحية. هدفت هذه الدراسة إلى تحديد مستوى رضا ع المواطنين التواصل مع الأطباء في مراكز الرعاية الصحية الأولية ومعرفة العلاقة بين رضا المواطنين والتركيبة السكانية والاجتماعية.

النتائج: التصميم الكمي ، أجريت دراسة وصفية مقطعية لتحديد مستوى رضا العميل تجاه مهارات الاتصال للأطباء في أربعة مراكز للرعاية الصحية الأولية. تم جمع البيانات في الفتزة من 15 أبريل 2019 إلى 1 يوليو 2019. لذلك تم اختيار 300 عميل بشكل عشوائي. النتيجةة : كان متوسط العمر + 10.8 + SD 35.0 سنة تتزاوح من 19 إلى 70 سنة. كان الوسيط 33 سنة. الغالبية (71\%) من العملاء الذين تقل أعمارهم عن 40 سنة. حوالي ثلثي العملاء (64.3\%) من الإناث ، و 80.3٪ من العملاء كانوا من المسلمين. حضر حوالي ثلث العملاء (34.3٪) مراكز الرعاية الصحية الأولية للتحصين ، و 32٪ للفحص ، و 23٪ للعلاج الطبي. يزور 34.4٪ من العملاء مركز الرعاية الصحية الأولية أكثر من أربع مرات في السنة ، و 26٪ يزورون المركز أربع مرات في السنة ، و 25٪ يزورون المركز ثلاث مرات في 
السنة. لا يوجد ارتباط معنوي بين مهارات الاتصال لدى الأطباء مع المتغيرات التالية: عمر العميل (ع = 0.096) ، الجنس (ع = 0.315) ، الدين (ع = 0.653) ، المستوى التعليمي (ع = 0.615) ، نوع خدمات الرعاية الصحية (ع = 0.469) ، وعدد الزيارات في السنة (ع = .$(0.089$

الخلاصة : كشفت الدراسة أن 26٪ من المواطنين راضون جداً عن مهارات التواصل لدى الطبيب ، و 36.3٪ راضون ، و 6.7٪ غير راضين. لم تكن هناك علاقة ذات دلالة إحصائية بين رضا المواطنين عن الأطباء بخصائصهم الاجتماعية والديموغرافية. الكلمات المفتاحية : مهارات الاتصال ،مستو ى رضى المواطنين ،الاطبا 


\section{REFRENCES:}

(PDF) Patients' satisfaction about nurses' competency in practicing communication skills [Internet]. [cited 2019 Aug 21]. Available from:

https://www.researchgate.net/publication/264792727_Patients'_satisfaction_about_nurses'_competency_in_practi cing_communication_skills

Siamian H, BagheriNesami M, Nia R, Nezhad F, Akbari H, Balaghafari A, et al. Assessment of Interpersonal Communication Skills Among Sari Health Centers' Staff. Mater Socio Medica [Internet]. 2014 [cited 2019 Jul 20];26(5):324. Available from: http://www.scopemed.org/?mno=172081

Ferreira M, Silva D, Pires A, Sousa M, Nascimento M, Calheiros N. Clinical Skills and Communication in Nursing Students. In 2016 [cited 2019 Aug 17]. p. 51-60. Available from:

http://www.futureacademy.org.uk/files/images/upload/5ichandhpsy2016.pdf

Vermeir P, Vandijck D, Degroote S, Peleman R, Verhaeghe R, Mortier E, et al. Communication in healthcare: a narrative review of the literature and practical recommendations. Int J Clin Pract [Internet]. 2015 Nov [cited 2019 Aug 17];69(11):1257-67. Available from: http://doi.wiley.com/10.1111/ijcp.12686

Dithole KS, Thupayagale-Tshweneagae G, Akpor OA, Moleki MM. Communication skills intervention: promoting effective communication between nurses and mechanically ventilated patients. BMC Nurs [Internet]. 2017 Dec [cited 2019 Aug 17];16(1):74. Available from: https://bmcnurs.biomedcentral.com/articles/10.1186/s12912017-0268-5

Hall P, Keely E, Dojeiji S, Byszewski A, Marks M. Communication skills, cultural challenges and individual support: challenges of international medical graduates in a Canadian healthcare environment. Med Teach. 2004 Mar;26(2):120-5. 
Ibrahim AF, Tawfik FM, Akel DT. Nurse communication in health education: Patients' perspective. Clin Nurs Stud [Internet]. 2015 Sep 15 [cited 2019 Aug 17];3(4). Available from: http://www.sciedupress.com/journal/index.php/cns/article/view/6914

Duffy FD, Gordon GH, Whelan G, Cole-Kelly K, Frankel R. Assessing Competence in Communication and Interpersonal Skills: The Kalamazoo II Report: Acad Med [Internet]. 2004 Jun [cited 2019 Aug 17];79(6):495507. Available from: http://content.wkhealth.com/linkback/openurl?sid=WKPTLP:landingpage\&an=00001888200406000-00002

Makoul G, Krupat E, Chang C-H. Measuring patient views of physician communication skills: Development and testing of the Communication Assessment Tool. Patient Educ Couns [Internet]. 2007 Aug [cited 2019 Aug 31];67(3):333-42. Available from: https://linkinghub.elsevier.com/retrieve/pii/S0738399107001784

Narenjiha M, Haghighat S, Bahaddor H, Shajari J, Jameie SB. The Importance of Physicians' Communication Skills and Patients' Satisfaction. Thrita [Internet]. 2012 Dec [cited 2019 Aug 31];1(2):57-61. Available from: http://thritajournal.neoscriber.org//?page=article\&article_id=5460

Biglu M-H, Nateq F, Ghojazadeh M, Asgharzadeh A. Communication Skills of Physicians and Patients' Satisfaction. Mater Socio-Medica [Internet]. 2017 Sep [cited 2019 Aug 21];29(3):192-5. Available from: https://www.ncbi.nlm.nih.gov/pmc/articles/PMC5644191/

Hamdan- Mansour A, Aboshaiqah A, Thultheen I, M Salim W, N Azzeghaiby S, A Anani M, et al. Patients' satisfaction about nurses' competency in practicing communication skills. Life Sci J. 2014 Jan 1;11.

Robert K, Hellen J, Japheth KC. Client Satisfaction with Communication Skills of Health Care Providers. :6.

Ashraf M, Ashraf F, Rahman A, (2012); Assessing women? s satisfaction level with maternity services: Evidence from Pakistan. International Journal of Collaborative Research on Internal Medicine \& Public Health.

Hildingsson I, Rådestad I (2005). Swedish women's satisfaction with medical and emotional aspects of antenatal care. $J$ Adv Nurs; 52(3):239-249.Available from https://www.ncbi.nlm.nih.gov/pubmed/16194177

Parizadeh M.J.,et.al,(2004) "Satisfaction rate of patients in three health centres of 14 saints. Shahid Ferdousi and Students of Mashhad City". Raze Behzisti journal; 12: 21-5. Available from https://vdocuments.mx/clientsatisfaction-with-communication-skills-of-health-satisfactionpdf.html 